\title{
Multi- and long-segment spinal arteriovenous fistula
}

Xuefeng Tian, MM, Xing Zhang, MD, Lei Ye, MD, and Hongwei Cheng, MD

Neurology ${ }^{\circledR}$ 2020;95:180-181. doi:10.1212/WNL.0000000000009834

A 56-year-old man complained of hypesthesia in the right lower extremity for 2 months. The same symptoms gradually involved the left lower extremity. Recent onset of dysuria was reported. Physical examination revealed diminished tendon reflexes in both lower extremities and diminished superficial and position sensation in the groin. MRI revealed a vascular malformation, ranging from T9 to L1 (figure). Spinal vessel digital subtraction angiography indicated a spinal dural arteriovenous fistula in the arteria radicularis magna arising from the right L1 intercostal artery and an intradural perimedullary arteriovenous fistula arising from the vertebral artery at $\mathrm{C} 2$ (video 1 ).

\section{Study funding}

No targeted funding reported.

\section{Disclosure}

The authors report no disclosures relevant to the manuscript. Go to Neurology.org/ $\mathrm{N}$ for full disclosures.

Figure Magnetic resonance angiography of the vascular malformation

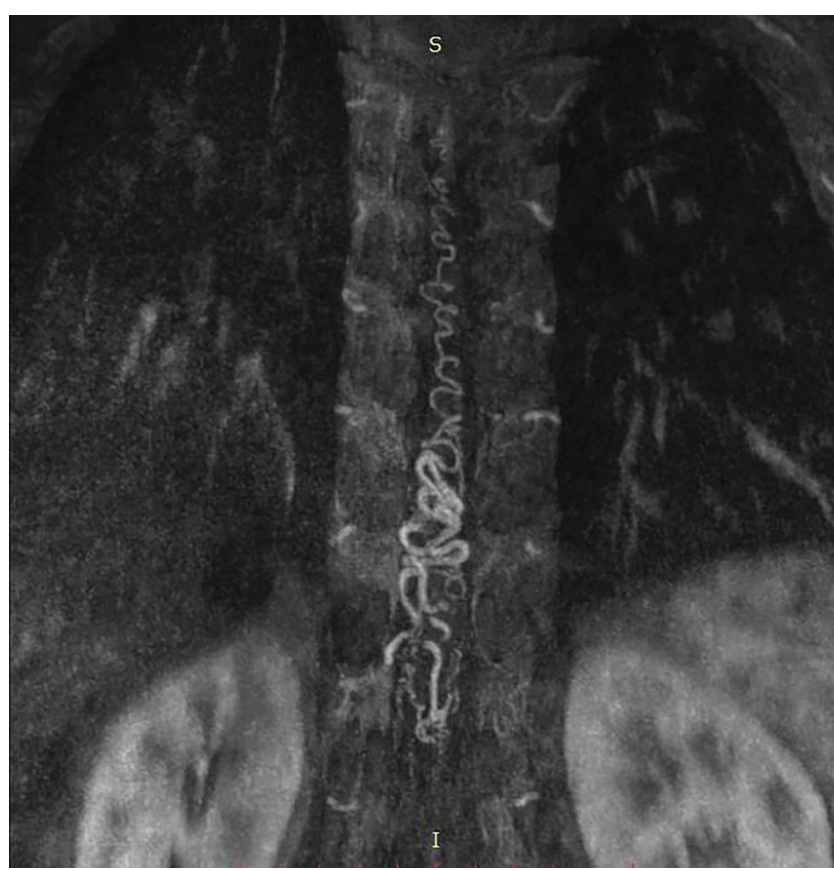

The vascular malformation ranged from T9 to L1.

\author{
Correspondence \\ Dr. Cheng \\ hongwei.cheng@ \\ ahmu.edu.cn
}

\section{MORE ONLINE}

○ Video

From the Department of Neurosurgery, First Affiliated Hospital of Anhui Medical University, Hefei, China.

Go to Neurology.org/N for full disclosures. 
Appendix Authors

\begin{tabular}{lll}
\hline Name & Location & Contribution \\
\hline $\begin{array}{l}\text { Xuefeng } \\
\text { Tian, MM }\end{array}$ & $\begin{array}{l}\text { First Affiliated Hospital of } \\
\text { Anhui Medical University }\end{array}$ & $\begin{array}{l}\text { Main surgical operator and } \\
\text { data collection }\end{array}$ \\
\hline $\begin{array}{l}\text { Xing } \\
\text { Zhang, }\end{array}$ & $\begin{array}{l}\text { First Affiliated Hospital of } \\
\text { MD }\end{array}$ & $\begin{array}{l}\text { Main surgical operator and } \\
\text { director }\end{array}$ \\
\hline
\end{tabular}

Appendix (continued)

\begin{tabular}{lll}
\hline Name & Location & Contribution \\
\hline Lei Ye, MD & $\begin{array}{l}\text { First Affiliated Hospital of } \\
\text { Anhui Medical University }\end{array}$ & $\begin{array}{l}\text { Drafting and revision of the } \\
\text { manuscript }\end{array}$ \\
\hline $\begin{array}{l}\text { Hongwei } \\
\text { Cheng, } \\
\text { MD }\end{array}$ & $\begin{array}{l}\text { First Affiliated Hospital of } \\
\text { Anhui Medical University }\end{array}$ & $\begin{array}{l}\text { Decision maker for the } \\
\text { surgical method and revision } \\
\text { of the manuscript }\end{array}$
\end{tabular}

\section{New, Free Mobile Learning App Offers Complimentary Self-assessment CME}

The American Academy of Neurology is pleased to offer a new, mobile educational resource-free to AAN members! The Neurology Question of the Day mobile app offers a quick, convenient, and fun way to assess your knowledge and fulfill selfassessment CME requirements. Get started at AAN.com/QODapp.

\section{Call for Biostatisticians to peer review for Neurology ${ }^{\circledR}$}

We are seeking qualified experts to review the biostatistical aspects of submitted articles. We welcome those specializing in biostatistics with a background in experimental design and the review of randomized clinical trials, observational studies, genetic studies, and imaging studies in the neurodegenerative diseases.

If interested, please send CV to the Neurology Editorial Office: journal@neurology.org.

\section{Disputes \& Debates: Rapid online correspondence}

The editors encourage comments on recent articles through Disputes \& Debates:

Access an article at Neurology.org/N and click on "MAKE COMMENT" beneath the article header. Responses will be posted as rapidly as possible.

Before submitting a comment to Disputes \& Debates, remember the following:

- Disputes \& Debates is restricted to comments about articles published in Neurology within the last 8 weeks

- Read previously posted comments; redundant comments will not be posted

- Your submission must be 200 words or less and have a maximum of 5 references; the first reference must be the article on which you are commenting

- You can include a maximum of 5 authors (including yourself) 


\section{Neurology}

\section{Multi- and long-segment spinal arteriovenous fistula \\ Xuefeng Tian, Xing Zhang, Lei Ye, et al. \\ Neurology 2020;95;180-181 Published Online before print June 19, 2020 \\ DOI 10.1212/WNL.0000000000009834}

This information is current as of June 19, 2020

$\begin{array}{ll}\begin{array}{l}\text { Updated Information \& } \\ \text { Services }\end{array} & \begin{array}{l}\text { including high resolution figures, can be found at: } \\ \text { http://n.neurology.org/content/95/4/180.full }\end{array} \\ \text { Subspecialty Collections } & \begin{array}{l}\text { This article, along with others on similar topics, appears in the } \\ \text { following collection(s): } \\ \text { All Spinal Cord } \\ \text { http://n.neurology.org/cgi/collection/all_spinal_cord } \\ \text { Arteriovenous malformation } \\ \text { http://n.neurology.org/cgi/collection/arteriovenous_malformation }\end{array} \\ & \begin{array}{l}\text { Information about reproducing this article in parts (figures,tables) or in } \\ \text { its entirety can be found online at: } \\ \text { http://www.neurology.org/about/about_the_journal\#permissions } \\ \text { Permissions \& Licensing }\end{array} \\ \text { Information about ordering reprints can be found online: } \\ \text { http://n.neurology.org/subscribers/advertise }\end{array}$

Neurology ${ }^{\circledR}$ is the official journal of the American Academy of Neurology. Published continuously since 1951, it is now a weekly with 48 issues per year. Copyright (C 2020 American Academy of Neurology. All rights reserved. Print ISSN: 0028-3878. Online ISSN: 1526-632X.

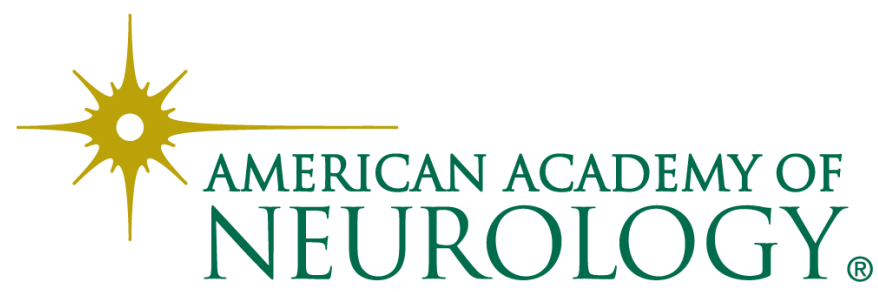

